\title{
Effectivity of Pipper crocatum leaf solution on plaque
}

\author{
Biofoma Mohentaeses Veransa*, Dede Hadidjah*, Nunung Rusminah* \\ *Department of Periodontics Faculty of Dentistry Universitas Padjadjaran, Indonesia
}

\begin{abstract}
Chemical plaque control has been proven effective on decreasing the plaque growth. This research was conducted to determine the effectivity of Pipper crocatum leaf solution for controlling dental plaque. The type of this research was a quasi-experimental research using the crossover design and the double blind system. The research sample consisted of 30 female student of Faculty of Dentistry Universitas Padjadjaran, chosen by purposive sampling method. The research subject get treated two times, which were gargled with Pipper crocatum leaf solution or with mineral water three times in two days. Plaque value was assessed using Quiqley and Hein Modified Index by Turesky, Gilmore and Glickman. The plaque scoring was performed on the third day. The data was analyzed by the independent t-test. Results: There was a decrease in the plaque value of the subject that gargled with Pipper crocatum leaf solution, whereas in the subjects gargled with mineral water was found an increasing plaque value. Statistical calculations given the results that there was a significant difference in the plaque value between subjects gargled with Pipper crocatum leaf solution and mineral water. The conclusion of this research was that gargling with Pipper crocatum leaf solution was effective to prevent dental plaque growth.
\end{abstract}

Keywords: Pipper crocatum, dental plaque, plaque index.

\section{INTRODUCTION}

The formation of dental plaque is an early process of the onset of periodontal disease. Dental plaque contains many different type of bacteria that can cause damage of the tooth tissue and periodontal tissue through the substance produced by plaque. Plaque formation can be prevented by removing the activity of plaque bacteria on the tooth surface. One of the prevention of plaque accumulation can be done by using antiseptic agent such as mouthwash. ${ }^{1,2}$ Antiseptic agent contained in mouthwash is needed to maintain good oral hygiene and healthy oral cavity by killing or preventing bacterial growth ${ }^{3}$. Antiseptic is obtained from chemical solution or natural ingredients contained in the plants contained in nature, including Pipper crocatum leaf.

Pipper crocatum leaf is one of tropical plants from Indonesia. Characteristic of this tropical plant is round stem, green or purplish and no flower. The leaves stem is the shape of a heart and the top is tapered and the surface of the leaves is shiny. Pipper crocatum leaf grown propagate to the growth medium, such as on the fence or propagate on the larger trees. The Pipper crocatum leaf can reach a height of 15 meters. Pipper crocatum leaf consists of various types, such as green betel, betel dutch, clove betel, yellow betel, betel black and red Pipper crocatum leaf. ${ }^{4}$ Pipper crocatum leaf well known to the Indonesia people and used as an antiseptic and 
antimicrobial agent. ${ }^{5}$ Based on the types of Pipper crocatum leaf that exist, red Pipper crocatum leaf is the type of leaf that is now widely used in the community. ${ }^{6}$ Red Pipper crocatum leaves have higher fragrant aroma than other types of Pipper crocatum leaves. In general, red Pipper crocatum leaves are used by people to treat toothache, eliminate bad breath, stop gum bleeding and treat canker sores. ${ }^{7}$ Sudewo in 2010 had stated that red Pipper crocatum leaf contains a number of active compounds that have antibacterial power, such compounds include flavonoids, alkaloid, tannin, and essential oils. ${ }^{8}$ Flavanoids act as antibacterial by forming complex compounds against extracellular proteins that will interfere with the integrity of bacterial cell walls. The content of alkaloids in red Pipper crocatum leaves has an antibacterial mechanism by interfering with the peptidoglycan component of the bacterial cell, so that the cell wall layer is not formed and causes the bacterial death. The tannin compound acts as an antibacterial by damaging the bacterial cell wall. ${ }^{9}$ According to Astuti in 2007, tannins can also shrink the cell wall of bacteria that can interfere with the permeability of the cell. ${ }^{5}$ The permeability of the substance causes the cells to not live activity so that growth is inhibited and cause bacterial death. The content of essential oils in red Pipper crocatum leaf works by disrupting the process of cell wall formation so that the cell wall is not formed perfectly.

The purpose of this research was to determine the effectiveness of red Pipper crocatum leaf solution to prevention of plaque formation on tooth. It is expected to obtain useful information theoretically about the effectiveness of gargling with red Pipper crocatum leaf solution to prevent the formation of plaque on the teeth in improving efforts to maintain hygiene and oral health and practical information about red Pipper crocatum leaf solution as a preventive of the formation of plaque can be used generally.

\section{METHODS}

This type of research was a experimental with cross-over method and double blind system. Population in this research was 110 student class of 2008 Faculty of Dentistry Universitas Padjadjaran. The sample was taken by purposive sampling technique that was as many as 30 people who have met the criteria. Sample criteria in this research were as follows: student of Faculty of Dentistry Universitas Padjadjaran class of 2008; not currently on antibiotic therapy; no cervical caries or overhang patches; not using fixed or removable orthodontic appliance; the arrangement of teeth was not crowded and there was no diastema; willing to be the subject of research.

The materials used in this research were red betel leaf solution, mineral water as control, $70 \%$ alcohol, and disclosing solution. The tool used in this research were cotton pellet, petri dish, glass of medicine, glass of mouth, sonde, tweezers, mouth gargle, mask and gloves, informed consent, stationery and examination form and tissue.

The procedure of the researched were described as follows. The sample was taken based on predetermined criteria which as as much as 30 people. The sample was divided into two groups, each group consisted of 15 people. Each subject was asked to gargle with mineral water as a control and red Pipper crocatum leaf solution. Prior to treatment, research subjects first given an explanation of the research to be performed and given informed consent as evidence of approval and willingness of the subject of research.

The first day before being treated to each study subjects was skeletal or prophylactic to get a clean oral cavity so that the plaque value was equal to zero. Group I was gargled with mineral water and Group II was gargled with red Pipper crocatum leaf solution. The researcher instructed the research subjects to gargle the dosage of each gargle using $25 \mathrm{ml}$ of mouthwash for 30 seconds for 2 days. Gargling done three times a day, which were morning after breakfast, lunch after dinner and night before bed. Each subject of research was told to gargle in the same way which was by moving the muscles of the cheeks, lips, and tongue to the maximum.

During the study, the study subjects were not allowed to perform oral hygiene measures (brushing and using other aids) in addition to gargling with the given solution. The third day was performed the plaque examination on the subject. The wash-out period was for three days. Subjects were allowed to perform oral hygiene measures as usual. Scaling was done before the subjects were re-treated.

The second treatment, the researchers instructed the research subjects to gargle again in the same way but using different solutions for two days. Group I was gargled with red Pipper crocatum leaf solution and group II was gargled with mineral water.

Assessment of plaque using Quigley and Hein modified Turesky-Gilmore-Glickman modified index. Teeth examined on the basis of Ramfjord are $1.6,2.1,2.4,3.6,4.1,4.4$. Surface teeth observed include 2 surfaces, namely buccal/labial and lingual/palatal. Research criteria were as follows: 0 = no plaque; 1 = there were plaque spots on the cervical tooth, the plaque was present on the other part above the cervical tooth; 2 = there was a thin layer of continuous plaque (up to $1 \mathrm{~mm}$ ) 
in the cervical area; $3=$ there was a thin layer of plaque of more than $1 \mathrm{~mm}$ but covering less than $1 / 3$ of the dental crown; $4=$ plaque covering between $1 / 3$ to $2 / 3$ of the crown portion of the tooth $5=$ plaque over $2 / 3$ of the crown of the tooth.

Calculation of plaque index was the amount of plaque value of each examined tooth covering two buccal and lingual surfaces, except for the third molar, divided by the entire surface of the examined tooth. Data obtained from the results of the study were analyzed by statistical test that is normality test and independent t-test.

\section{RESULTS}

The plaque index value of each study subjects in the first experiment was shown below.

In Figure 2 showed the plaque index of the study subjects in the first experiment in which group I gargled with mineral water and group II gargled with red Pipper crocatum leaf solution. It was seen that plaque value in the group gargled with mineral water was much higher than the group with red Pipper crocatum leaf solution. The plaque index of the gargling group with mineral water was averaged 3 and 4 .

Figure 3 showed the plaque index of the study subjects in the second experiment in which group I gargled with red Pipper crocatum leaf solution and Group II gargled with mineral water. It was seen that the plaque index on the group with mineral water was much higher than the group of red Pipper crocatum leaf solution. Group with mineral water were having the plaque index in the average of 3 and 4.

The plaque index values from the first and second experiments were then tested with independent $\mathrm{t}$-test, to obtain the mean value of the plaque index of both trials. The mean values of first and second experimental plaques can be

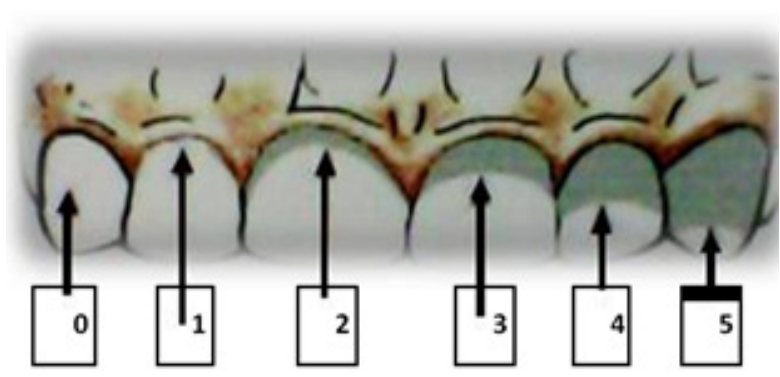

Figure 1. Quigley-Hein Plaque Index ${ }^{10}$

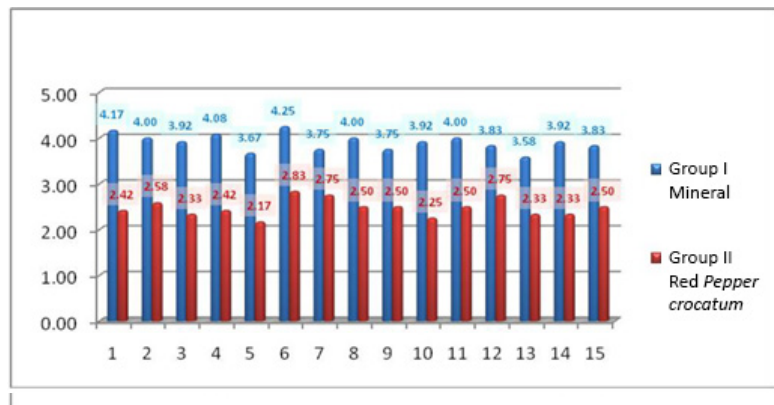

Figure 2. Plaque index diagram of the first experiment, Group I gargle with mineral water and Group II gargle with red Pipper crocatum leaf solution

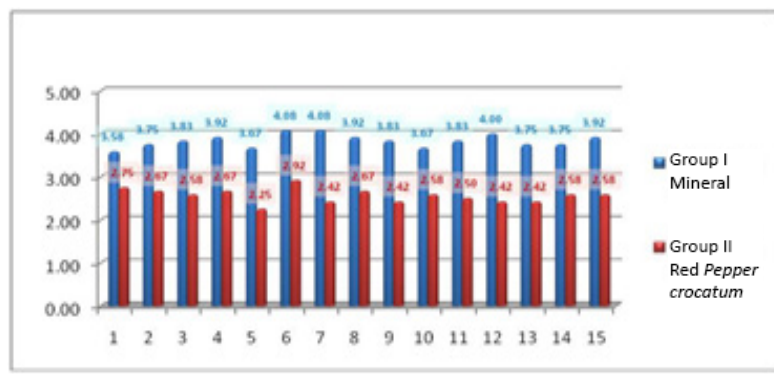

Figure 3. Plaque index diagram of the second experiment, Group I gargle with mineral water and Group II gargle with red Pipper crocatum leaf solution

Table 1. Mean plaque index $( \pm \mathrm{SD})$ after gargling with mineral water and red Pipper crocatum solution

\begin{tabular}{|l|l|c|c|c|}
\hline & \multicolumn{1}{|c|}{ Groups } & N & Mean \pm SD & p \\
\hline First Trial & Group 1 (mineral water) & 15 & $3.91 \pm 0.18$ & $\mathrm{p}<0.05$ \\
\hline & $\begin{array}{l}\text { Group 1 (Red pipper crocatum leaf } \\
\text { solution) }\end{array}$ & 15 & $2.47 \pm 0.18$ & $\mathrm{p}<0.05$ \\
\hline $\begin{array}{l}\text { Second } \\
\text { Trial }\end{array}$ & Group 1 (mineral water) & 15 & $3.83 \pm 0.14$ & $\mathrm{p}<0.05$ \\
\hline & $\begin{array}{l}\text { Group 1 (Red pipper crocatum leaf } \\
\text { solution) }\end{array}$ & 15 & $2.56 \pm 0.16$ & $\mathrm{p}<0.05$ \\
\hline
\end{tabular}


seen in Table 1.

Table 1 showed that there was a difference in mean values of plaque index in the first and second experiments between the group with mineral water and the gargling group of red Pipper crocatum leaf solution. The mean values of the red Pipper crocatum leaf solution in the first and second experiments were $2.47 \pm 0.18$ and $2.56 \pm 0.16$, respectively. The plaque index value is smaller than that of the gargling group with mineral water. From the results of calculations with independent $t$ test it can be seen that gargling with red betel leaf solution significantly reduced the formation of plaque.

\section{DISCUSSION}

From the results of calculations with independent t-test it can be seen that gargling with red Pipper crocatum leaf solution significantly reduces the formation of plaque. This may be due to red betel leaves containing substances that have antibacterial power to reduce plaque formation in teeth. Substances contained in red Pipper crocatum leaves have different ways of working to kill bacteria. Flavanoid contained in red Pipper crocatum leaf works as an antibacterial by forming complex compounds that can interfere with the integrity of bacterial cell walls and the formation of bacterial cell walls. ${ }^{11,9}$ Tannin compound in red Pipper crocatum leaves serves to shrink the bacterial cell wall so that bacterial growth is hampered and can cause death of bacterial cells. The alkaloid compound works by disrupting the peptidoglycan component of the bacterial cell resulting in impaired cell permeability so that the lining of the cell wall is not fully formed and causes inhibition of cell growth and bacterial death. Essential oil serves to disrupt the formation of cell walls resulting in coagulation of proteins that cause bacterial cell walls to lysis. ${ }^{9}$ These active substances contained in red Pipper crocatum leaf that will inhibit and kill plaque bacteria, so the process of plaque formation on the teeth can be prevented and oral health will be better.

\section{CONCLUSION}

The conclusion of this research was that gargling with Pipper crocatum leaf solution was effective to prevent dental plaque growth.

\section{REFERENCES}

1. Manson JD, Eley BM. Outline of Periodontics 3rd ed. London: Elsevier Health Science; 1995. p. 14-22.

2. Newman MG, Takei HH, Carranza FA. Carranza's Clinical Periodontology. 9th ed. Philadelphia: Saunders-Elsevier; 2002.

3. Arif A, Sjamsudin U. Farmakologi dan Terapi. 4th ed. Jakarta: UI Press; 1995. p. 501-522.

4. Sastroamidjojo AS. Obat Asli Indonesia. 1997. Jakarta: Dian Rakyat.

5. Astuti HD, Praba FW, Ayu IY, Roeslan BO, Sjahruddin L. Efek aplikasi topikal laktoferin dan Piper betle Linn pada permukaan mukosa mulut terhadap perkembangan karies. Majalah Ilmiah Kedokteran Gigi. 2007;22(1):28-31.

6. Sudewo B. Basmi Penyakit dengan Sirih Merah. Jakarta: AgroMedia Pustaka; 2010. p. 40-50, 80-5.

7. Haviva AB. Sirih Merah Itu Obat Dahsyat. Yogyakarta: Laksana; 2011. p. 11-9.

8. Sudewo B. Basmi Penyakit dengan Sirih Merah. Jakarta: AgroMedia Pustaka; 2010. p. 40-50, 80-5.

9. Juliantina F, Citra DA, Nirwani B, Nurmasitoh T, Bowo ET. Manfaat sirih merah sebagai agen anti bakterial terhadap bakteri gram positif dan gram negatif. Ind J Med Health. 2009;1(1):12-20.

10. World Health Organization. Oral Health Country/Area Profile Programme Quigley Hein Index Modified by Turesky et al. Geneva: World Health Organization; 1970.

11. Dwidjoseputro D. Dasar-dasar Mikrobiologi. Jakarta: Djambatan; 2005. 